4. Ринок Інтернет-реклами у Східній та Центральній Свропі. - Режим доступу: http://www.gemius.com.ua/vse-stati-dlja-chtenija/rynokinternet-reklamy-v-regione-centralnoj-i-vostochnoj-evropy.html

5. Тертичний О. Особливості маркетингу в мережі Інтернет / О. Тертичний // Економіка та суспільство. - 2017. - №12. - С. 382-385.

6. Gamova I. V. Development trends of electronic trade in Ukraine. / I. V. Gamova // Actual Problems of Economics. - 2014 (4). - № 11 (161). - P. 371-379. (SciVerse Scopus).

DOI: http://doi.org/10.31617/k.knute.2019-03-19.77

\title{
РЕЛІГІЯ ЯК ІНСТРУМЕНТ ІНФОРМАЦІЙНО-ПСИХОЛОГІЧНОГО ВПЛИВУ
}

\author{
Юрко Т. В. \\ студентка 3 курсу \\ кафедра маркетингу \\ Гамова I. B. \\ к.е.н., доцент \\ кафедра журналістики та реклами \\ Київський національний торговельно-економічний університет, \\ Україна
}

Ключові слова: інформаційно-психологічний вплив, види впливу, інструменти впливу, релігія.

Keywords: informational psychological influence, types of influence, influence's tools, religion.

Сучасний час характеризується інтенсивним застосуванням різноманітних методів інформаційного, психологічного, технологічного пресингу, що особливо пов'язано з розвитком сучасних технологій, дозволяючих впливати на свідомість і психіку великої кількості людей одночасно без взаємодії і прямого контакту з ними. Актуальною була i $є$ проблема психологічного впливу на свідомість людей в різних сферах життєдіяльності суспільства.

Інформаційне середовище все чіткіше набуває характеру другої, суб'єктивної реальності. Проте сприймається ця реальність істотним зовнішнім джерелом загроз інформаційно-психологічної безпеки особистості.

Андрій Курпатов (вчений психотерапевт) каже, що мозок домальовує реальність. Зорове і слухову сприйняття світу не є стовідсотковим. 
За стільки часу еволюції, ми - великі ссавці, навчилися будувати стійкі зв'язки між звуками, які чуємо, між образами, які бачимо [1]. Досить зрозуміти функціонування людського сприйняття і влинути на маси стає зовсім неважко. У людей дуже багато «слабких місць».

Інформаційно-психологічний вплив (часто його називають інформаційно-пропагандистським, ідеологічним) - це вплив словом, інформацією. Основною метою такого психологічного впливу $\epsilon$ формування певних ідеологічних (соціальних) ідей, поглядів, уявлень, переконань, одночасно воно викликає у людей позитивні або негативні емоції, почуття і навіть бурхливі масові реакції. Так, листівка, надаючи пропагандистський вплив (тобто впливаючи на свідомість), може одночасно викликати психологічні переживання, наприклад відчуття туги за батьківщиною, за родиною. У період Другої світової війни радянські листівки 3 віршами Е.Вайнерта «Подумай про свою дитину», що розповсюджувалися серед німецьких військовослужбовців, чинили на них сильний емоційний вплив [2].

Інформаційно-психологічний вплив складається 3 двох основних видів: спонукання і примус.

1. Спонукання об'єкта інформаційно-психологічного впливу до здійснення будь-яких дій - відкритий вплив на свідомість об'єкта, в результаті якого в свідомості відбувається формування мотивації до здійснення певних вчинків.

Спонукання є основним відкритим методом управління як в міжособистісній взаємодії, так і в процесах взаємодії особистості і суспільства, особистості і держави, держави і громадських організацій.

2. Примус як вид інформаційно-психологічного впливу - вплив на свідомість об'єкта, в результаті якого в свідомості об'єкта відбувається формування мотивації для обов'язкового здійснення певних вчинків всупереч власній волі чи бажанню [3].

На прикладі спонукання об'єкта інформаційно-психологічного впливу до здійснення будь-яких дій ми розгляемо питання релігії.

Релігія являє собою багатофункціональний духовний системоутворюючий феномен, який впливає на саму особу, іiі соціальні взаємини і взаємодії, а також соціальні групи і спільноти. У площині релігійної уваги знаходяться соціокультурний і моральний розвиток людей.

За даними American Pew Research Center на період 2010 року 98\% людей є прихильниками певного віросповідання, з яких 33,2\% належать християнам. І відповідно 2\% атеїстів [4].

Як трансляція найдавніших культурних цінностей, релігія, грунтуючись на духовному аспекті, надає допомогу людині у важких 
життєвих ситуаціях? Чи дійсно вона може сприяти вирішенню проблем особистісного, соціального і екзистенціального характеру? Служителі культу і богослови, які ділять релігії на справжні, частково справжні і несправжні, вважають, що справжні релігії відіграють безумовно позитивну роль, помилкові - безумовно негативну, а частково справжні - суперечливу роль. Серед атеїстів $є$ і такі, які вважають, що будь-яка релігія відіграє лише негативну роль. Вони, як правило, керуються висловом В. І. Леніна, який назвав релігію (релігію взагалі, будь-яку релігію) «ворогом культури і прогресу».

Усунення стародавніх манускриптів дало можливість створити псевдо-історію і відрізати людство від його справжніх коренів. Маніпулювати історією надзвичайно важливо, тому що то, як люди бачать своє минуле, впливають на сьогодення і майбутнє.

Вся Біблія - це могутній інструмент підсвідомого впливу, повний окультних чисел, послань, алегорій і краденого матеріалу древніх релігій. Крім того, Біблія пронизана психічною енергією i силою збудження страху і віри в те, що вона реальна.

Ці так звані «релігії» (християнство, мусульманство та іудаїзм) побудовані на тортурах, вбивствах і брехні, і єдиний спосіб вижити для брехні таких жахливих масштабів - це постійно створювати нову брехню, руйнуючи тих, хто знає правду. Християнство - це не більше, ніж програма. У ній немає нічого ні духовного, ні релігійного. Адже вони переписані і запозичені в релігіях, що виникали значно раніше. Людству набагота більше років, ніж здається. Величезне число людей страждає депресією, безнадією і безцільністю свого існування, а маніпулювати стає все простіше і доступніше.

Прості громадяни дуже люблять моральність. Вони лають аморальне телебачення, але дивляться його. Вони гніваються на аморальну жовту пресу, але споживають іï. Вони паплюжать сучасні звичаї, але жити, як в Середньовіччі, не хочуть. Вони дуже шанують Біблію як «основу моральності», але читати ії не бажають. Хто ж в нашій країні $\epsilon$ монополістом в області моральності? Якщо опитати сто людей, абсолютна більшість на автоматі дадуть відповідь: - Церква! Слово це в свідомості громадян лежить поруч зі словами «моральність», «релігія», «біблія», «православ'я», «бог», «християнство». При цьому більшість людей, щиро називають себе віруючими, про християнство мають досить поверхневе уявлення, до церкви ходять тільки на екскурсію, з попами не спілкуються, а Священне писання, як уже говорилося, ніколи не читали. Але ж Біблія для віруючих - базова річ, як для марксиста «Капітал» [5]. 


\section{Список використаних джерел}

1. Курпатов А. В. Красная таблетка. - 2018. 270 с.

2. Спецслужбы и войска особого назначения. - Режим доступу: info.wikireading.ru/220884

3. Baranov E.G. National Psychological Journal 2017, no. 1

4. Последователи религий. - Режим доступу: ru.wikipedia.org/wiki/ Численность_последователей_основных_религий

5. Никонов А.П. Опиум для народа. Религия как глобальный бизнеспроект. - 2009. - 344 с.

DOI: http://doi.org/10.31617/k.knute.2019-03-19.78

\section{РЕКЛАМНА ПІДТРИМКА СТИМУЛЮВАННЯ ПРОДАЖУ}

\section{Юсупова О.В.}

к.е.н., старший викладач

кафедра журналістики та реклами

Київський національний торговельно-економічний університет, Украӥна

Ключові слова: реклама, стимулювання продажу, стимулювання збуту, изінове стимулювання, акиії.

Keywords: advertising, sales promotion, $B O G O F$.

Стимулювання продажу $є$ самостійним та одним 3 основних інструментів маркетингових комунікацій підприємства, проте найбільшої ефективності досягає в поєднання з рекламою. Реклама надає стимулюванню продажу необхідної інформаційної підтримки та представляє потенційному покупцеві передбачену акцією вигоду. Одну і ту саму вигоду в рекламі можна представити кількома різними методами.

Найпростішим та найбільш розповсюдженим засобом цінового стимулювання продажу є пряме зниження цін. Представлення даного засобу стимулювання продажу в рекламі може приймати різний вигляд за багатьма ознаками і по-різному впливати як на обсяг реалізації товару в поточному періоді, так і на ціну, яку покупець буде вважати справедливою для даного товару в майбутньому.

Пряму знижку на товар підприємство може зазначити у відсотках або у грошових одиницях. Дослідження показали, що обидва варіанти представлення знижки є однаково цікавими для покупців, проте саме знижки у грошовому вираженні негативно впливають на порівняльну ціну, знижуючи іiі [1]. Такий результат пояснюється 